\title{
Columnar Metaplasia
}

National Cancer Institute

\section{Source}

National Cancer Institute. Columnar Metaplasia. NCI Thesaurus. Code C35846.

A morphologic finding indicating the transformation of non-columnar epithelial cells into columnar cells. 